\title{
Multi-stakeholder Governance in Cooperative Organizations: Toward a New Framework for Research?
}

\author{
Catherine Leviten-Reid \\ Cape Breton University \\ Brett Fairbairn \\ University of Saskatchewan
}

\begin{abstract}
Despite the increasing popularity of multi-stakeholder cooperatives, social-economy researchers largely predict that these organizations will fail. Using a "cost of decision-making" approach, these researchers conclude that the governance structure of multi-stakeholder cooperatives makes this organizational model fundamentally untenable. In this paper, we review the empirical evidence available on multi-stakeholder cooperatives, which suggests that different groups of actors are able to govern themselves successfully. Consequently, we argue that the literature that has focused on the management of common pool resources by self-organized groups may be an appropriate body of literature in which to root a research program on these social-economy organizations.
\end{abstract}

\section{RÉSUMÉ}

Malgré la popularité grandissante des coopératives à multiples intervenants, les chercheurs en économie sociale prédisent que ces organisations essuieront un échec. Grâce à une méthode des coûts pour la prise de décisions, ces chercheurs en viennent à la conclusion que la structure de gouvernance des coopératives à multiples intervenants, par sa nature, en fait un modèle organisationnel indéfendable. Dans cet article, nous examinons les éléments de preuve empiriques disponibles sur les coopératives à multiples intervenants, qui suggèrent que différents groups d'actants peuvent réussir à s'autogérer. Par conséquent, nous discutons du fait que la documentation qui porte sur la gestion des ressources communes par les groupes autogérés pourrait constituer un corpus approprié pour établir un programme de recherche sur ces organisations d'économie sociale.

\section{Keywords / Mots clés}

Governance; Cooperatives; Multi-stakeholder / Gouvernance; Coopératives; Coopératives de solidarité 


\section{Leviten-Reid and Fairbairn (2011)}

\section{INTRODUCTION}

Over the past two decades, legislation has been amended or created in Europe and parts of North America to facilitate and formalize the development of multi-stakeholder cooperatives ${ }^{1}$. The purpose of these organizations is to pursue social-economic goals; a range of actors are formally involved in decision-making in order to meet a common objective, be it the provision of a needed service or the economic revitalization of a community. Curiously, although multi-stakeholder legislation has been encouraged by cooperative developers and increasingly adopted by law-makers (Girard, 2004), scholars largely predict that the type of governance structure that these organizations embody will cause them to fail. A common view is that multi-stakeholder cooperatives are fraught with high decision-making costs caused by self-interested actors or by cumbersome decision-making processes, and so they may either revert to governance structures in which single stakeholder groups dominate, or will cease operating altogether (see, for example, Lindsay \& Hems, 2004; Münkner, 2004; Tomas, 2004).

There is, so far, limited empirical evidence available on the governance of multi-stakeholder cooperatives, but this evidence appears to show that different groups of actors involved in decision-making are able to successfully govern their organizations. Such successes may indicate that using a cost approach for framing research on this organizational form may be an inappropriate place to begin. Instead, it may be more useful, as a starting point, to think of multi-stakeholder co-operatives as those that are able to pursue common interests, and to begin to research how they are able to govern themselves effectively.

This article presents an exploratory foray into the theory and practice of multi-stakeholder cooperatives, and it does so in four sections. The first provides background information on key terminology and on the emergence of the multi-stakeholder model of cooperative organizations. The second section outlines how scholars have used a cost approach to predict and explain the ownership structure of firms, with particular application to multistakeholder involvement in decision-making. The third section reviews available empirical evidence, while the final section proposes both a different starting point for understanding decision-making within this kind of socialeconomy organization and presents a set of factors that could be considered when researching the governance of multi-stakeholder cooperatives.

\section{BACKGROUND}

\section{Multi-stakeholder co-operatives}

It is increasingly evident among scholars who study firms of different types that all organizations have multiple stakeholders, defined as those who can affect or who are affected by the organization; or, those who have a stake (Freeman, 1984). Typically these include owners or sponsors; managers; customers, clients, or users; employees; volunteers; lenders; suppliers; community residents; and community organizations. Even a profitmaximizing firm needs to pay some attention to these groups if it is to be fully successful (Freeman, 1984), and in fact these firms may incorporate stakeholders beyond shareholders, such as a small number of employees, on their boards of directors. Similarly, the boards of directors of nonprofit organizations would typically consider the needs of their multiple constituencies when making decisions, such as the organizations' clients and funding agencies. Participation in these nonprofit organizations by various stakeholder groups may even take place in a more direct fashion: they may have advisory groups or committees comprised of different constituencies that report to the board, and they may collect information from key stakeholders through surveys (Brown, 2002; LeRoux, 2009). Moreover, social-economy organizations of all kinds, including micro-lending institutions, nonprofits providing social services, and fair-trade social enterprises, may feature the representation of key constituencies at the board table (see, for example, LeRoux, 2009; Huybrechts, 2010; Hartarska, 2005). 


\section{Leviten-Reid and Fairbairn (2011)}

The focus of this paper is on a particular type of organization within the social economy in which the involvement of more than one group of actors in decision-making is an inherent feature; namely, the multistakeholder cooperative. A multi-stakeholder co-operative typically has at least two classes of members identified in its by-laws, such as consumers, workers, investors, volunteers, or representatives from other organizations. Each class of member would also have designated seats at the board table. Although there are different ways to allocate the voting rights of the association's members, one method is for the members of each stakeholder group, on a one-member, one-vote basis, to vote for which of their peers should fill the board seats allocated to their group (Lund, 2010). These elected directors from different stakeholder groups would then have to work together to carry out the normal functions ascribed to a board of directors, such as ensuring the financial health of the organization, hiring and overseeing the work of managers, and strategic planning (Stone and Ostrower, 2007). In the case of a multi-stakeholder cooperative that distributes any surplus to its members, the board of directors would also have to decide how this amount would be allocated to the members in its different constituency groups (Lund, 2010).

Exactly which voices, as well as the extent to which different constituencies participate in the governance of multi-stakeholder cooperatives, depends on the organizations' by-laws, but also on the legislation that shapes these organizations in their respective jurisdictions. In Québec, where multi-stakeholder governance has been formalized through the Co-operatives Act, different groups of actors that are recognized by the legislation include consumers, workers, and supporting members (defined as individuals or organizations with an economic, social or cultural interest in the objectives of the organization). Only the participation of two of the aforementioned groups is necessary for the formation of a multi-stakeholder co-operative. Boards of directors must feature at least one individual from each stakeholder group that is part of the cooperative and, in the case of multi-stakeholder cooperatives in which supporting members are a stakeholder group, only up to one-third of directors may be from this category (Gouvernement du Québec, 2009). In adjacent Ontario, Canada, however, the actors who are to be represented in decision-making are not formally delineated in cooperative law. Rather, the legislation simply defines stakeholder groups as those that are bound by a shared interest or geography. In terms of their level of participation on the board, organizations must set out the number of directors to be elected by each group in their articles of incorporation (Province of Ontario, 2009); in other words, there is no minimum or maximum amount of seats pre-established through the Co-operative Corporations Act.

\section{Governance}

Generally speaking governance refers to situations and mechanisms of regulation and control within groups, systems, or organizations. Despite its long history, the word has become common only in the last four decades or so and is often used today to refer particularly to the proper exercise of control by boards of directors within organizations, and especially the relations between boards and managers (Bouchard, 2004). Following this usage there are numerous discussions of board governance, policy governance, and so on (Carver and Carver, 1997, provide an example of a framework). But the word governance is also used in a more general sense, as when policymakers discuss governance of natural resources or of international conflict. We may distinguish this broad sense of the word governance as one which concerns the question "who has a voice in decisions?" somewhat different from a more particular sense, such as "what is the role and authority of a board?"

In this article, our use of the term governance draws on both senses of the word, as we consider both the voices of multiple constituencies within a specific type of organization, as well as how these different voices jointly carry out normal board functions. Our focus on governance also includes the participation of members of these cooperatives at members' meetings, where reports are delivered and questioned, resolutions are introduced 


\section{Leviten-Reid and Fairbairn (2011)}

and debated, and new directors are elected. Although important, governance, as used in this article, does not encompass the relationship between the board of directors and managers within these organizations.

\section{The emergence of multi-stakeholder cooperatives}

One of the rationales for explaining the emergence of social-economy organizations of any kind is that they respond to market and government failures. Failure, in this context, is taken to mean failure of the institution to perform a predicted role, such as the failure of a market to produce competition, to be efficient, and to meet consumer needs; or the failure of a state to provide for the well-being of its people. In this perspective, socialeconomy organizations emerge when other institutions, notably the market and the state, fail to meet needs. For example, many social economy scholars argue that the first formal co-operative store formed in the United Kingdom as a response to high-cost consumer goods combined with a lack of legislation to prevent the adulteration of foodstuffs (Hoyt, 2003; MacPherson, 2009). Similarly, producer cooperatives formed in Western Canada in order to address a monopoly in the storage and distribution of grain (Fairbairn, 2005).

Yet, while earlier cooperatives were focused on correcting failures by emphasizing the needs of a single type of member, newer models have emerged in which cooperatives focus on issues that affect the wider community and that are addressed through the involvement of different types of actors (Levi, 2001). For example, food stores in rural or marginalized communities that are no longer deemed viable by sole proprietors or corporations have been purchased by local actors and incorporated as multi-stakeholder cooperatives in order to address not only the supply of essential consumer goods, but also high unemployment and rural outmigration (Lindsay \& Hems, 2004). Boards of directors of these organizations are reflective of this different conceptualization of the problem at hand, and may include seats not only for consumers and staff, but also for local groups, such as regional development corporations or voluntary sector organizations.

As a second example, the current struggles of agricultural producers are also viewed widely to encompass not only the well-being of farm families, but also rural communities (Haaf \& Stefanson, 2001). New cooperative structures have emerged across Canada and the United States that allow non-user members to invest in valueadded enterprises; local residents "choose to purchase preferred shares because they want to support development in their communities and encourage job and wealth creation close to home" (Haaf \& Stefanson, 2001, p. 4). Owners of preferred shares are, at least in some jurisdictions, provided with some rights to participate in decision-making; for example, they may be allowed to elect a certain number of directors to the board (Province of Saskatchewan, 2009).

While the exact cause of this broadened focus on the part of cooperative organizations, as well as the concomitant involvement of multiple actors, is unclear, one trend that has likely facilitated the development of this new type of social-economy organization is the stakeholder construct that has emerged from the corporate governance literature, detailed by R. Edward Freeman (1984) and much elaborated since then. Using this framework, the role of management is not to respond exclusively to the expectations of shareholders, but to make decisions that positively affect the well-being of all stakeholders. The wide popularity of the stakeholder construct in literature concerning corporate governance means there may be spill-over into discussions of the functioning of other organizational forms, since such discussions often draw on the corporate governance literature. Andrew Friedman and Samantha Miles (2006) discuss the increasing use of corporate governance concepts in the nonprofit literature since 1984, and beyond this literature there are examples of corporate governance practices affecting, being adopted within, or being imposed on the social economy. For example, Brett Fairbairn, Christopher Axworthy, Murray Fulton, Lou Hammond Ketilson and David Laycock (1990) describe how Canadian cooperative law has been shaped, to a significant degree, in order to resemble corporate law. 


\section{Leviten-Reid and Fairbairn (2011)}

\section{High costs}

Decision-making involving different groups of actors has been deemed difficult, and often untenable, due to the high costs associated with governance of multi-stakeholder cooperatives. This framework is often used, either directly or implicitly, by social economy scholars to hypothesize the governance processes of multi-stakeholder cooperatives. In the literature, Antonio Tomas (2004) writes that the governance costs of multi-stakeholder cooperatives in Italy are likely high, featuring conflict among groups of actors. Hans Münkner (2004) writes that these organizations are slower to make decisions and may feature one group of dominate stakeholders; similarly, Graeme Lindsay and Les Hems (2004) also argue that dominant stakeholder groups may emerge in multi-stakeholder structures.

The construct of governance or decision-making costs was put forward by Henry Hansmann (1996) as a variable that helps explain the presence of different types of firms, including investor-owned firms versus cooperatives, versus nonprofit organizations, in different sectors of the economy. In this framework, the costs of participation in decision-making are one of a number of transaction costs with which organizations must deal if they are to be successful. While all transaction costs may affect organizational performance, in this article we are concerned only with decision-making costs associated with participation of multiple stakeholder groups. Hansmann (1996) argues that the involvement of different parties in decision-making is costly and also, therefore, uncommon. Inefficiencies arise for two main reasons. To begin, different groups of individuals are considered to have fundamentally divergent interests, and may be apt to resolve issues and pursue strategic directions in a manner that advances their own well-being versus the well-being of the larger group to which they belong. This may be exacerbated by factors such as stakeholder groups of unequal size, and thus unequal representation, in decision-making; certain actors may also simply be more engaged in decision-making than others. Here, decisions are said to be costly because they do not maximize the well-being of the entire group. Second, even if groups of individuals do not prioritize their own interests, the steps necessary for understanding the perspectives and preferences of different stakeholders and achieving consensus on different issues is argued to be too cumbersome and time consuming.

It is worth noting that decision-making costs are posited to be high both within organizations that involve delineated stakeholder groups in governance, such as an organization with consumers and workers on the board of directors, as well as organizations with single types of members who have heterogeneous interests (for example, a worker cooperative that involves a wide range of skills and specializations). As a result of these high costs, neither type of organization is argued to be common. As empirical evidence of the latter type of organization being impeded by high decision-making costs, Hansmann writes that worker cooperatives tend to operate in sectors where the output produced requires workers with relatively uniform skills sets. Interestingly, Hansmann (1996) writes that the transaction costs of the delineated multi-stakeholder model are "enormous" (p. 44) and supports this statement by writing that there is a "nearly complete absence of large firms in which ownership is shared among two or more different types of patrons, such as customers and suppliers or investors and workers" (p. 44). While Hansmann's focus in this excerpt is on large firms, high decision-making costs are argued to be present in all firms that feature multi-stakeholder governance.

In general, then, theory predicts that multi-stakeholder cooperatives will fail either in the ultimate sense of ceasing to exist, or in the definitional sense of failing to accomplish their intended purpose and tending, over time, to revert to what amounts to single-stakeholder dominance. 


\section{Leviten-Reid and Fairbairn (2011)}

\section{A look at the evidence}

A small amount of empirical evidence exists on multi-stakeholder cooperatives. What is noteworthy is that most of the evidence refutes the prediction that these organizations will either close their doors or begin to function as organizations dominated by single stakeholder groups. For example, Tomas (2004) admits that the struggles experienced by Italian multi-stakeholder cooperatives cannot be attributed to their governance structures. He explains that different stakeholder groups are in fact able to maintain a focus on the overall mission and goals of these organizations; to illustrate, volunteer members typically contribute their time to these social cooperatives for altruistic reasons rather than to pursue individual interests. Similarly, investors are commonly donors committed to the social outcomes of these cooperatives and are not focused on financial returns. Despite postulating that there are high costs associated with the multi-stakeholder model, Münkner (2004), too, writes that the governance process likely results in both greater trust among actors and better information.

A survey of multistakeholder cooperatives located in Québec reveals very high levels of satisfaction with governance processes ( $N=73$ ) (Chagnon, 2004). Over $90 \%$ of respondents reported that the participation by different stakeholder groups at board meetings was excellent and, moreover, so too was the ability to achieve consensus among different actors. Further, when asked to identify upcoming challenges, most respondents stated that economic issues, such as increasing total revenue and paying higher staff wages, were of concern to them, rather than problems related to decision-making. Interestingly, the author of this Québec report identified several trends that one could, without the feedback on satisfaction with outcomes, interpret as indicators of governance problems. For example, the proportion of board seats per category of member does not always reflect how membership is distributed within these multi-stakeholder organizations, and, although there are typically more consumer than worker members in these organizations, a greater proportion of worker members attend annual meetings. These findings reflect two issues discussed directly by Hansmann (1996) as leading to unwieldy decision making costs for organizations; specifically, the strong worker presence at members' meetings reflects potentially uneven levels of active engagement among stakeholder groups, while stakeholder groups are of unequal size. Still, survey results point to multi-stakeholder organizations that are able to successfully engage in collective decision-making.

Four case studies on multistakeholder cooperatives in Québec also provide some understanding of governance in these organizations (Langlois and de Bortoli, 2004; 2006a; 2006b; Langlois and Girard, 2005). These case studies explore the impact of the organizational model on social cohesion; because one of the dimensions of this construct is democracy, this research does consider internal decision-making processes. Specifically, researchers looked at how boards of directors of multi-stakeholder cooperatives functioned (that is, whether different stakeholders were able to work well together or not) and how members of these cooperatives participated more broadly in these organizations.

What emerges from these case studies is that at the board level, three out of the four organizations experienced minimal conflict among directors representing different stakeholder groups. Moreover, participants from the boards of two of these organizations stated that any differences in opinion served to enrich discussions during meetings. The fourth case study was somewhat inconclusive in terms of the nature of decision-making at the board table. Research participants stated that they were able to achieve consensus in board decisions among three types of members: their supporting members, their users, and their users who also invested in the enterprise. The worker member was described as being interested in human resources issues more than any other matter; still, directors stated that divergent opinions were "assets that kept the organization moving along" (our translation) (Langlois and de Bortoli, 2006b). Case study findings also point to a disproportionate level of 


\section{Leviten-Reid and Fairbairn (2011)}

participation by worker members at the members' meetings of two organizations. Overall, these case study findings mirror the survey results presented by Jocelyne Chagnon (2004).

Finally, since the low number of large organizations with multi-stakeholder decision-making structures has been cited as evidence of high transaction costs (Hansmann, 1996), the tremendous growth of smaller organizations that have adopted this model over the past fifteen years should also be considered as counter-evidence. For example, the multi-stakeholder model is the legal form of choice for recently incorporated cooperatives in Québec; almost half of all cooperatives formed in 2006 in this province chose this governance structure, and ten percent of the total number of cooperatives in this jurisdiction are now multi-stakeholder (Lepage, 2007). In Italy, there are over 7,000 such organizations (Tomas, 2004).

Further research is needed to investigate whether the pattern of substantial success we have noted for multistakeholder cooperatives is borne out more widely and whether success will be maintained over time. The current evidence, however, seems sufficient to suggest the need for new theoretical frameworks that do not emphasize so heavily or so one-sidedly the transaction costs of governance.

It is worth noting that because of the small amount of literature available specifically on the governance of multistakeholder cooperatives, we also expanded our literature search to include the governance of other kinds of social-economy organizations, including social enterprises and nonprofit organizations, as long as they featured different constituencies which were represented at the board table. We do not consider these organizations to be identical to multi-stakeholder cooperatives because they most likely differ in terms of how different classes of members are delineated in by-laws (if indeed they are formally delineated at all) as well as in how the voting rights of these members are allocated. Note that the papers we reviewed for this additional literature search provided little information on the exact governance structures of the organizations being researched.

What did emerge from this literature search is that among social-economy organizations more broadly, there is little evidence regarding how decisions are made at the board table. Roger Spear, Chris Cornforth and Mike Aiken (2009) found that staff and directors reported both negative and positive aspects to multi-stakeholder governance in social enterprises in the United Kingdom; for example, some research participants stated that stakeholder groups may emphasize their own needs or interests rather than those of the social enterprise as a whole. Further, having large funders represented at the board table may lead to "conflicts of interest and excessive monitoring." (Spear, Cornnforth \& Aiken, 2009, p. 268). In contrast, other respondents felt that having funders involved in decision-making led to stronger ties and good communication. A study on fair-trade social enterprises in Belgium also found mixed effects regarding the multi-stakeholder composition of boards of directors (Huybrechts, 2010): while the representation of divergent stakeholder groups allowed organizations to take advantage of different skill sets and fulfill both their social and economic missions, interview data revealed that directors with business expertise felt encumbered by the input of volunteers with non-business backgrounds.

What also emerged from this literature search was that while there is some existing research on how stakeholder representation on boards of directors is related to performance (for example, Valentina Hartarska [2005] looks at whether having staff and borrowers on the boards of micro-lending organizations is associated with their financial sustainability and lending practices to low-income clients, while the first author of this article [2010] examines the relationship between parent representation on the boards of child-care centres and the quality of care provided), this literature does not explore the board processes that result in these organizational outcomes. Consequently, while this paper puts forward a new starting point for research on multi-stakeholder cooperatives, the questions asked here may also apply more broadly to social-economy organizations of different kinds. 


\section{Leviten-Reid and Fairbairn (2011)}

\section{Toward a new framework?}

Although social economy scholars commonly use a cost approach when writing about multi-stakeholder cooperatives and then predict that the governance costs associated with these organizations are ultimately too high to allow them to function effectively, the available empirical evidence suggests that, in fact, multistakeholder models often work. Different groups of actors are able to pursue shared objectives of the organization rather than exclusively their own needs, and effective decision-making processes can be established that allow for the input of different actors and consensus-building among their representatives at the board table.

Arguably, then, a new framework that holds different assumptions about decision-making among diverse sets of actors may be more appropriate for pursuing research on multi-stakeholder cooperatives. Moreover, research is needed that sheds light on how such organizations' governance processes take place as well as on any factors that may be important in explaining variation in the successful governance of these organizations. Indeed, it is noteworthy that in extant literature on the topic, the data that have been collected predominantly focus on how actors perceive the governance model to be working, rather than on governance processes themselves.

A promising body of literature for developing a framework and pursuing research on decision-making in multistakeholder cooperatives may be that which focuses on self-organized groups that manage common-pool resources. These groups manage natural or human-made resources that are finite, and where one person's use of what is available in the common pool affects what is left for others to draw upon (Ostrom, 1990). Selforganized groups develop and modify their own governance structures and rules for how common-pool resources should be used and monitored by members, although how these actors are able to use these resources is also shaped in part by rules beyond those that they establish themselves; in other words, by local or national laws (Ostrom, 2000). Finally, these self-organized groups are typically comprised of individuals with different needs with regard to the resource they co-manage; for example, they may need to withdraw different amounts of water from a watershed in order to irrigate land holdings of different sizes. These groups may have a heterogeneous membership in different respects as well; for example, actors may vary in terms of their cultural backgrounds or other socio-demographic characteristics (Varughese and Ostrom, 2001).

Conceptually, while the functions of boards of directors of cooperative organizations do not mirror the management of common-pool resources by local actors, there is arguably important overlap. Most basically, both endeavours involve different actors with potentially divergent interests working together to establish and carry out rules, roles, and responsibilities regarding how resources or assets will be managed for the group as a whole. Further, as in the co-management of a resource, different groups of actors in a multi-stakeholder cooperative may theoretically make decisions about how to use the association's resources in a way that could reduce what is available for others. For example, in the case of a health services organization in which both workers and consumers are on the board of directors, a proposal by workers to raise wages or their benefits package would impact the budget available to enhance services for consumers; this might lower the resources available to devote to the health centre's information library targeted to users of the organization, or it might reduce the budget available to provide transportation services for client-members to get to and from appointments. As such, these multi-stakeholder organizations need to create governance processes that allow directors to balance the needs of different stakeholders to ensure the financial sustainability of the organization. Further, the governance of multi-stakeholder cooperatives is also shaped and constrained by legislation that affects how they approach decision-making2; like groups of individuals managing common pool resources, then, they seldom operate in a completely autonomous fashion. Moreover, the large body of empirical work on the successful management of common-pool resources by local groups emerged as counterevidence to an assumption that individuals behave in a self-interested manner, resulting in the ultimate destruction of 


\section{Leviten-Reid and Fairbairn (2011)}

resources. This parallels what the findings of the review of the empirical evidence on multi-stakeholder cooperatives presented above; namely, that organizations involving different groups of actors in decisionmaking are able to do so without reverting to a single-stakeholder organization or to an organization that closes its doors, despite assumptions to the contrary.

Empirical work has uncovered processes that lead to successful and sustainable governance of common-pool resources (Ostrom, 2000); several seem salient to explore in research on the governance of multi-stakeholder cooperatives. For example, one process that contributes to good governance is that all actors are involved, or at least have the opportunity to be involved, in the formation and reformulation of rules that dictate how the group functions and how the resource is managed; in other words, rule making is not done by a select group of individuals. This participatory approach is argued to not only foster a sense of involvement, but also create trust among individuals. A second factor is that there is a clear understanding of which individuals are part of a common-pool resource system, as well as of the rights and obligations of these members. A third important factor is that conflicts are resolved quickly, meaning that mechanisms are in place to identify, discuss, and address problems. Finally, common-pool resources are governed well when their members perceive a fair relationship between what individuals invest in the management of the resource and the extent to which they benefit. For example, in the case of a watershed being managed by a group of agricultural producers for the purposes of irrigation, producers who invest more in monitoring water usage should also be entitled to greater access to water for his or her crops and livestock, in mutual agreement with other members of the group (Ostrom, 2000).

Interestingly, some of these findings seem similar to governance strategies recommended by authors examining how to achieve successful governance within multi-stakeholder cooperatives in the social economy, although none of the following recommendations have been tested empirically. For example, Münkner (2004) recommends meaningful participation channels in order to engage all types of members in these organizations, and states that those playing leadership roles should work hard to establish an active membership. Similarly, Chagnon (2004) recommends frequent members' meetings for multi-stakeholder cooperatives in Québec, as well as opportunities for training and education, as ways to foster active participation of members. With respect to clearly defining how individuals are involved in these organizations, Chagnon (2004) also notes that approximately $20 \%$ of multi-stakeholder cooperatives have members with dual status; in other words, these members are both workers and consumers in the same organization, but yet the by-laws of these organizations do not address, define, or limit their rights and responsibilities. As a result, the author recommends that organizations amend their by-laws to address this issue in order to ensure good, long-term governance.

It is also worth noting that the empirical work on common-pool resources has also uncovered factors that lead to the emergence of self-organized groups (Ostrom, 1992; Ostrom, 2000). Community organizing skills or leadership experience seems to play a role; researchers have also pointed to the presence of an existing sense of trust among actors and an existing and shared understanding of the role that the common-pool resource plays in people's lives as important variables. Finally, self-organized groups may emerge to manage commonpool resources when such resources are vital to the very livelihood of the actors involved. All seem pertinent to explore by social economy scholars launching research on why community actors adopt multi-stakeholder versions of cooperative organizations, as well as what makes such structures successful.

\section{CONCLUSION}

This article has argued that, despite the common assumption held by researchers that multi-stakeholder cooperatives will fail due to a decision-making structure that is inherently costly, available empirical evidence on these cooperatives suggests that different groups of actors are, in fact, able to govern themselves successfully and pursue shared goals. We argue that research that has focused on the emergence and sustainability of self- 


\section{Leviten-Reid and Fairbairn (2011)}

organized groups that form to manage common-pool resources may be an appropriate place to couch a research program that explores the governance processes of multi-stakeholder cooperatives. Participant observation of board meetings and in-depth interviews with directors may be useful methods to allow the governance processes of these organizations to come to the fore; survey research with a larger number of multi-stakeholder organizations could then follow. Key research foci could include not only the processes and strategies used by directors to achieve consensus and carry out their board functions, but also an examination of where else and how else multi-stakeholder decision-making may take place (such as within committees), and how the boards of multi-stakeholder cooperatives work with management. Research could also explore the role of group dynamics in achieving consensus at the board table, or identify the important external and internal factors that influence successful multi-stakeholder governance over time. For example, such external factors might include the economic environment, the availability of technical assistance (such as through a regional cooperative development centre) or the density of a cooperative network in the region in which the multistakeholder cooperative is located. Internal factors might include the commitment of the manager to working closely with the board of directors, or the overall commitment of the organization to democratic principles. Results could both inform scholarly work on governance in the social economy, and help inform emerging multistakeholder cooperatives on the strategies they may want to adopt to help ensure that different actors are able to participate fully and work together for the benefit of a shared goal.

\section{ACKNOWLEDGEMENTS}

We would like to acknowledge the funding provided by the Social Sciences and Humanities Research Council of Canada. We would also like to acknowledge the helpful comments made by Murray Fulton, John Whitman, and three anonymous reviewers on earlier drafts of this article.

\section{NOTES}

1. We use the word "formalizes" because cooperatives involved different stakeholder groups in governance before the creation of new legislation. For example, an amendment made in 1978 to the Medical Benefit Associations Act in Saskatchewan, Canada (the legislation under which health cooperatives were first incorporated in that province) made it possible for up to one-third of the directors of these organizations to be staff (Province of Saskatchewan, 1978), with the remainder of seats allocated to consumers. As a second example, after the 1997 amendments to cooperative law that allowed for the formation of multi-stakeholder cooperatives in Québec, many existing nonprofit organizations changed their articles of incorporation to multi-stakeholder cooperatives (Chagnon, 2004), which suggests that they were already harnessing input from different groups of actors, but without a formal structure to support this type of governance as bona fide cooperative organizations. According to Carlo Borzaga and Alceste Santuari (2004), Italy also featured a large number of social-economy organizations that involved multiple stakeholder groups in governance before the introduction of new cooperative law allowed them to formally incorporate as multi-stakeholder cooperatives.

2. Legislation on multi-stakeholder cooperatives in Ontario is a case in point. Before amendments to the Co-operative Corporations Act in 2009, multi-stakeholder cooperatives were required to have a minimum of one director representing each stakeholder group in order to achieve quorum at board meetings. This requirement was difficult for organizations to meet, and so was removed from the Act at the urging of the cooperative sector (On Co-op, 2009).

\section{REFERENCES / BIBLIOGRAPHIE}

Borzaga, C. \& Santuari, A. (2004). Italy: From traditional co-operatives to innovative social enterprises. In C. Borzaga \& J. Defourny (Eds.), The emergence of social enterprise (pp. 166-181). New York, NY: Routledge.

Bouchard, Marie J. (2004). La gouvernance, une vieille et une nouvelle réalité pour l'économie sociale. Économie et Solidarités, 35, (1-2), 16-25. 


\section{Leviten-Reid and Fairbairn (2011)}

Brown, William. (2002). Inclusive governance practices in nonprofit organizations and implications for practice. Nonprofit Management and Leadership, 12(4), 369-376.

Carver, John, \& Miriam Mayhew Carver. (1997). Reinventing Your Board: A Step-by-Step Guide to Implementing Policy Governance. San Francisco, CA: Jossey-Bass.

Chagnon, J. (2004). Les coopératives de solidarité au Québec. Québec, QC : Direction des coopératives, Ministère du Développement économique, de l'Innovation et de l'Exportation, Gouvernement du Québec.

Fairbairn, B. (2005). Canada's co-operative province: Individualism and mutualism in a settler society. Occasional Paper Series, Centre for the Study of Co-operatives. Saskatoon, SK: University of Saskatchewan.

Fairbairn, B., C.S. Axworthy, M. Fulton, L.H. Ketilson, \& D. Laycock. (1990). Co-operative institutions: Five disciplinary perspectives. In M. Fulton (Ed.), Co-operative organizations and Canadian society: Popular institutions and the dilemmas of change (pp. 13-38). Toronto, ON: University of Toronto Press.

Freeman, R.E. (1984). Strategic management: A stakeholder approach. Toronto, ON: Pitman.

Friedman, A.L., \& S. Miles. (2006). Stakeholders: Theory and practice. New York, NY: Oxford University Press.

Girard, J.-P. (2004). Solidarity co-operatives in Québec (Canada): Overview. In C. Borzaga \& R. Spear (Eds.), Trends and challenges for co-operatives and social enterprises in developed and transition countries (pp. 165-182). Trento, Italy: Edizioni31.

Gouvernement du Québec. (2003). Loi sur les coopératives. Québec, QC: Éditeur Officiel du Québec.

Haaf, C. \& B. Stefanson. (2001). New generation co-operatives and the law in Saskatchewan. Centre for the Study of Co-operatives. Saskatoon, SK: University of Saskatchewan.

Hansmann, H. (1996). The ownership of enterprise. Cambridge, MA: The Belknap Press of Harvard University Press.

Hartarska, V. (2005). Governance and performance of microfinance institutions in Central and Eastern Europe and the Newly Independent States. World Development, 33(10), 1627-1643.

Hoyt, A. (2003). Consumer ownership in capitalist economies: Application of theory to consumer cooperation. In C. D. Merrett and N. Walzer (Eds.), Cooperatives and local development: Theory and applications for the 21st century (pp. 265-289). Armonk, N.Y.: M.E. Sharpe.

Huybrechts, B. (2010). The governance of fair trade social enterprises in Belgium. Social Enterprise Journal, 6(2), 110-124.

Langlois, G., \& P. de Bortoli. (2004). La coopérative de solidarité en aide domestique Domaine-du-Roy et son impact sur la cohésion sociale. Centre de recherche sur les innovations sociales. Montréal, QC: Université du Québec à Montréal.

Langlois, G., \& P. de Bortoli. (2006a). The case of la coop de solidarité en soins et services de Saint-Camille and its impact on social cohesion. Saskatoon, SK: Centre for the Study of Co-operatives, University of Saskatchewan.

Langlois, G., \& P. de Bortoli. (2006b). La coopérative de solidarité recreotouristique du Mont Adstock et son impact sur la cohésion sociale. Centre de recherche sur les innovations sociales. Montréal, QC: Université du Québec à Montréal.

Langlois, G., \& J.-P. Girard. (2005). La coopérative de solidarité en alimentation saine L'Églantier du Kamouraska et son impact sur la cohésion sociale. Montréal, QC: Centre de recherche sur les innovations sociales, Université du Québec à Montréal.

Lepage D. (2007). Coopératives du Québec: Données statistiques. Québec, QC: Direction des coopératives, Ministère du Développement économique, de l'In The case of la coop de solidarité en soins et services de Saint-Camille and its impact on social cohesion novation et de l'Exportation, Gouvernement du Québec. 


\section{Leviten-Reid and Fairbairn (2011)}

Leroux, K. (2009). Paternalistic or participatory governance? Examining opportunities for client participation in nonprofit social service organizations. Public Administration Review, 69, 504-519.

Levi, Y. (2001). 'Internal" and "external" principles. Review of International Co-operation, 94, 50-58.

Leviten-Reid, C. (2010). Organizational form, parental involvement and quality of care in child day care centers. Nonprofit and Voluntary Sector Quarterly, November 15, 2010, doi: 10.1177/0899764010388846.

Lindsay, G. \& L. Hems. (2004). Sociétés coopératives d'Intérêt collectif: The arrival of social enterprise within the French social economy. Voluntas: International Journal of Voluntary and Nonprofit Organizations, 15(3), 265-286.

Lund, M. (2010). Solidarity as a Business Model: A Multi-stakeholder Cooperatives Manual. Cooperative Development Center. Kent, Ohio: Kent State University.

MacPherson, I. (2009). A century of co-operation. Ottawa, ON: Canadian Co-operative Association.

Münkner H. (2004). Multi-stakeholder co-operatives and their legal framework. In C. Borzaga \& R. Spear (Eds.), Trends and challenges for co-operatives and social enterprises in developed and transition countries (pp. 49-82). Trento, Italy: Edizioni31.

On Co-op. (2009). 2009 Changes to the Co-operative Corporations Act. Guelph, ON: Author.

Ostrom, E. (1990). Governing the commons: The evolution for collective action. Cambridge: Cambridge University Press.

Ostrom, E. (1992). The rudiments of a theory of the origins, survival and performance of common-property institutions. In D. Bromley, (Ed.), Making the Commons Work: Theory, Practice and Policy (pp. 293-318). San Francisco, CA: ICS Press.

Ostrom, E. (2000). Reformulating the commons. Swiss Political Science Review, 6(1), 29-52.

Province of Ontario. (2009). Co-operative corporations act. Toronto, ON: Queen's Printer for Ontario.

Province of Saskatchewan. (1978). The mutual medical and hospital benefit associations act. Regina, SK: The Queen's Printer.

Province of Saskatchewan. (2009). The new generation co-operatives act. Regina, SK: The Queen's Printer.

Spear R., C. Cornforth, \& M. Aiken. (2009). The governance challenges of social enterprises: evidence from a UK empirical study. Annals of Public and Cooperative Economics, 80(2), 247-273.

Stone, M. \& F. Ostrower. (2007) Acting in the public interest? Another look at research on nonprofit governance. Nonprofit and Voluntary Sector Quarterly, 36(3), 416-438.

Tomas, A. (2004). The rise of social cooperatives in Italy. Voluntas: International Journal of Voluntary and Nonprofit Organizations, 15(3), 243-263.

Varughese, G. \& E. Ostrom. (2001). The contested role of heterogeneity in collective action: Some evidence from community forestry in Nepal. World Development, 29(5), 747-765.

\section{About the authors}

Catherine Leviten-Reid is Assistant Professor in the Shannon School of Business, Cape Breton University. Email: catherine_leviten-reid@cbu.ca

Brett Fairbairn is Provost and Vice President Academic, Professor of History, and Centre for the Study of Cooperatives Fellow in Co-operative Thought and Ideas, University of Saskatchewan. Email: provost.vpacademic@usask.ca 